\begin{tabular}{|c|c|}
\hline $\begin{array}{l}\text { JURTAL } \\
\text { MANAVEMUEN] } \\
\text { KEWURAUSAHLAN] }\end{array}$ & $\begin{array}{r}\text { p-ISSN 1858-1048 } \\
\text { e-ISSN 2654-9247 } \\
\text { http://ejurnal.stieipwija.ac.id/index.php/jmk } \\
\text { DOI: http://dx.doi.org/10.33370/imk.v16i1.301 } \\
\text { Jurnal Manajemen Kewirausahaan Vol. 16 No. 01 - Juni } 2019 \\
\text { Submit: } 6 \text { Mei 2019; Review: 17 Jun 2019; Publish: } 30 \text { Jun } 2019\end{array}$ \\
\hline
\end{tabular}

\title{
PENGARUH KUALITAS PELAYANAN MEDIS DAN INOVASI LAYANAN ADMINISTRASI TERHADAP KEPUASAN PASIEN
}

\author{
Oleh: \\ Yoyo Indah Gunawan'1), Martono Saragih' ${ }^{2)}$ \\ yiguna.YG@gmail.com ${ }^{1)}$, garinggingw@yahoo.com ${ }^{2}$ \\ Sekolah Tinggi Ilmu Ekonomi IPWI Jakarta ${ }^{1,2)}$
}

\begin{abstract}
ABSTRAK
Pada penelitian ini ada dua tujuan. Tujuan pertama adalah untuk mengetahui pengaruh kualitas pelayanan medis terhadap kepuasan pasien pada Klinik Gracia Bogor dan tujuan kedua adalah untuk mengetahui pengaruh inovasi layanan administrasi terhadap kepuasan pasien pada Klinik Gracia Bogor.

Penelitian dilakukan di Klinik Gracia Bogor dengan mengambil 100 pasien sebagai sampel penelitian yang dihitung menggunakan rumus Slovin dari total populasi 5000 pasien pada margin error 10\%. Pengambilan data dilakukan dengan instrumen kuesioner tertutup lima skala penilaian dari sangat tidak setuju sampai dengan sangat setuju. Metode penarikan sampel dengan teknik non-probability sampling. Analisis regresi linear berganda digunakan sebagai alat analisis dan uji-F sebagai uji kelayakan model sedangkan pengujian hipotesis dilakukan dengan uji-t.

Penelitian menghasilkan dua temuan utama sesuai dengan hipotesis yang diajukan, yaitu: 1) Kualitas pelayanan medis memiliki pengaruh terhadap kepuasan pasien pada Klinik Gracia Bogor; 2) Inovasi layanan administrasi memiliki pengaruh terhadap kepuasan pasien pada Klinik Gracia Bogor.

Berdasarkan hasil temuan tersebut maka untuk meningkatkan kepuasan pasien disarankan agar terus meningkatkan kualitas pelayanan medis dan membuat inovasi pada layanan administrasi pada Klinik Gracia Bogor.
\end{abstract}

Kata Kunci: kualitas pelayanan medis, inovasi layanan administrasi, kepuasan pasien

\section{PENDAHULUAN}

Seiring dengan perkembangan dunia usaha yang begitu cepat membuat persaingan usaha menjadi sangat ketat, sehingga perusahaan yang bergerak di bidang usaha dituntut agar mampu bekerja lebih efektif dan efesien sebagai langkah menciptakan keunggulan bersaing. Selain itu juga, dalam menghadapi era globalisasi, lingkungan dunia usaha harus mampu mengatasi perubahan teknologi yang semakin canggih, sehingga penting membuat inovasi pada produk (barang atau jasa) di perusahaan yang berorientasi pada laba maupun nirlaba.

Salah satu industri kesehatan mulai tumbuh dengan pesat, hal ini dikarenakan masyarakat sudah menyadari betapa berharganya kesehatan bagi hidup mereka karena mengetahui mahalnya biaya perawatan kesehatan yang sering membuat masyarakat kesulitan untuk mendapatkan pelayanan kesehatan dengan baik sesuai dengan harapan 
mereka. Apalagi saat ini semakin banyak muncul penyakit-penyakit baru yang mengancam kesehatan masyarakat, maka perlu ada kesadaran yang tinggi di masyarakat akan pentingnya menjaga kesehatan dan masyarakat semakin kritis dalam memilih penyedia jasa kesehatan yang terbaik dan sesuai dengan apa yang mereka inginkan dan butuhkan.

Pertumbuhan usaha penyedia layanan kesehatan yang begitu pesat seperti rumah sakit, klinik, puskesmas, dan balai pengobatan, merupakan salah satu bukti dari meningkatnya kebutuhan masyarakat akan pelayanan kesehatan tersebut. Salah satu penyedia layanan kesehatan adalah Klinik Gracia di daerah Bogor tepatnya di Jl. Raya Narogong KM 17 pangkalan 9 Cileungsi, Bogor.

Menurut Utama (dalam Asmita,
hakikat dasar dari
penyelenggaraan dari pelayanan kesehatan adalah pemenuhan kebutuhan dan tuntutan dari para pemakai jasa pelayanan kesehatan (pasien), dimana pasien mengharapkan suatu penyelesaian dari masalah kesehatannya. Pasien memandang bahwa penyedia layanan kesehatan harus mampu memberikan pelayanan medis dengan kualitas yang terbaik dalam upaya penyembuhan penyakit dan pemulihan kesehatan yang berkualitas, cepat tanggap atas keluhan pasien, serta juga membuat inovasi pada pelayanan administrasi sehingga terbentuk pelayanan yang efektif dan efesien.

Salah satu faktor yang dapat mempengaruhi kepuasan pasien adalah kualitas pelayanan medis yang diberikan klinik kepada pasien tersebut. Unsurunsur yang membentuk pelayanan yang berkualitas merupakan perpaduan dari kualitas manusia yang dicerminkan oleh perilaku atau sikap pribadi dalam berinteraksi dengan para pengguna dan keterampilan atau keahlian yang merupakan penguasaan unsur-unsur teknik dan prosedur yang berkaitan dengan tugas pekerjaannya. Unsurunsur dan komponen-komponen dasar dalam pelayanan sulit untuk diinventori, maka dapat dikatakan bahwa pelayanan adalah berkaitan dengan proses, dimana produk yang dinikmati oleh pengguna berupa pengalaman (Sulastiyono, 2006:58).

Selain pelayanan medis, klinik juga melakukan inovasi pelayanan administrasi diterapkan karena konsumen menginginkan adanya pembaharuan dalam pelayanan yang dirasakan konsumen. Menurut Changkaew (2012), inovasi merupakan faktor pendorong utama dalam keberhasilan perusahaan. Tidak hanya di sektor industri, tetapi juga di sektor jasa. Sedangkan Delafrooz et.al (2013) menyatakan bahwa inovasi berkaitan dengan pelaksanaan tindakan-tindakan yang inovatif yang mengarah pada penciptaan produk atau jasa baru. Inovasi dapat dilakukan baik di produk ataupun pada jasa. Menurut Milles, 1993 (dalam Dhewanto dkk, 2014:94) konsep inovasi jasa meliputi inovasi pelayanan yang berkaitan dengan desain layanan dan pengembangan layanan baru.

Klinik Gracia menyediakan layanan kesehatan umum, gigi, kebidanan, dan kecantikan. Selain melayani pasien umum, klinik Gracia juga melayani peserta BPJS Kesehatan, BPJS Ketenagakerjaan dan peserta asuransi. Klinik Gracia dituntut untuk selalu menjaga kepercayaan konsumen dengan meningkatkan kualitas pelayanan medis dan membuat inovasi pelayanan administrasi agar kepuasan konsumennya meningkat.

Gambar 1

Jumlah kunjungan pasien klinik Gracia Bogor Tahun 2017

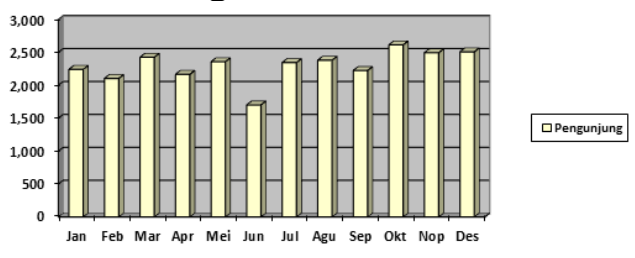

Sumber: Manajemen Klinik Gracia Bogor tahun 2018

Berkaitan dengan data kunjungan pasien Klinik Gracia pada tahun 2017 (gambar 1.1) yang berfluktuatif itu dapat sebagai gambaran fluktuasi kondisi kepuasan pasien Klinik Gracia Bogor. Mengingat hal tersebut, maka dalam penelitian ini perlu untuk mengetahui apakah kualitas pelayanan medis 
berpengaruh terhadap kepuasan pasien pada Klinik Gracia Bogor, dan apakah inovasi layanan administrasi berpengaruh terhadap kepuasan pasien pada Klinik Gracia Bogor.

\section{TUJUAN PENELITIAN}

Berdasarkan uraian di atas, maka tujuan penelitian ini adalah:

1. Untuk mengetahui dan menganalisis pengaruh kualitas pelayanan medis terhadap kepuasan pasien pada Klinik Gracia Bogor.

2. Untuk mengetahui dan menganalisis pengaruh inovasi layanan administrasi terhadap kepuasan pasien pada Klinik Gracia Bogor.

\section{TELAAH LITERATUR DAN PENGEMBANGAN HIPOTESIS}

Menurut Kotler dan Keller (2009:5), pemasaran adalah fungsi suatu organisasi dan serangkaian proses untuk menciptakan, mengkomunikasikan, dan memberikan nilai kepada pelanggan dan untuk mengelola hubungan pelanggan dengan cara yang menguntungkan organisasi dan pemangku kepentingannya.

Menurut Stanton (2002:4-5), pasar merupakan sistem keseluruhan dari kegiatan yang ditujukan untuk merencanakan, menentukan harga, mempromosikan, dan mendistribusikan barang dan jasa yang dapat memuaskan kebutuhan kepada pembeli yang ada maupun pembeli potensial. Berdasarkan definisi tersebut, maka dapat ditarik kesimpulan bahwa kegiatan bisnis harus berorientasi ke pasar atau konsumen. Keinginan konsumen juga harus dipuaskan secara efektif. Sebuah perusahaan untuk bisa bertahan di dalam pasar yang peka terhadap perubahan yang penuh persaingan saat ini apa yang bisa dijual, dan rancangan apa yang harus didayagunakan untuk memikat pelanggan yang waspada. Strategi pemasaran adalah serangkaian tindakan terpadu menuju keunggulan kompetitif yang berkelanjutan. Tujuan akhir dan konsep, kiat dan strategi pemasaran adalah kepuasan pelanggan sepenuhnya (Total Customer Statisfaction).

Menurut Kotler dan Armstrong (2009:6) ada lima langkah proses pemasaran, yaitu memahami pasar dan kebutuhan pelanggan, kebutuhan, keinginan dan permintaan, penawaran pemasaran (produk, jasa dan pengalaman), nilai dan kepuasan, serta pertukaran dan hubungan.

\section{Kualitas Pelayanan Medis}

Menurut Lewis dan Booms dalam Tjiptono (2007:121) mengemukakan bahwa kualitas pelayanan sebagai ukuran seberapa bagus tingkat layanan yang diberikan mampu sesuai dengan ekspektasi pelanggan. Kualitas pelanggan bisa diwujudkan melalui pemenuhan dan keinginan pelanggan serta ketepatan penyampaian untuk mengimbangi harapan pelanggan.

Menurut Haynes dan Du Vall yang dikutip Ariani (2009:178), kualitas pelayanan merupakan proses yang secara konsisten meliputi pemasaran dan operasi yang memperhatikan keterlibatan orang, konsumen internal dan konsumen eksternal, dan memenuhi berbagai persyaratan dalam penyampaian jasa.

$\begin{array}{ccr}\quad \text { Dimensi } & \text { kualitas } & \text { pelayanan, } \\ \text { Parasuraman } & \text { dkk } & (1985) \\ \text { mengembangkan } & \text { model } & \text { yang }\end{array}$ komprehensif dari mutu kualitas pelayanan kesehatan yang berfokus pada aspek fungsi dari pelayanan yaitu: Tangibles (tampilan fisik), Reliability (keandalan), Responsiveness (ketanggapan), Assurance (jaminan), dan Empathy (empati).

Beberapa definisi kualitas pelayanan di atas bagi penulis sebagai konsep dasar untuk diterapkan pada kualitas pelayanan medis, sehingga yang dimaksud kualitas medis sangat terkait dengan kualitas pelayanan tenaga medis, peralatan medis, dan obat-obatan medis yang didapat dan dirasakan oleh para pasien.

\section{Inovasi Layanan Administrasi}

Menurut Stephen Robbins (1994) mendefinisikan inovasi adalah sebagai suatu gagasan baru yang diterapkan 
untuk memprakarsai atau memperbaiki suatu produk atau proses dan jasa.

Menurut Delafrooz et.al (2013) menyatakan bahwa pengukuran inovasi layanan (indikator) dapat dilakukan melalui penggunaan teknologi, interaksi dengan pelanggan, pengembangan layanan baru, dan sistem pengiriman layanan.

Beberapa mengenai inovasi di atas bagi penulis sebagai konsep dasar untuk diterapkan pada inovasi layanan administrasi, sehingga yang dimaksud inovasi layanan administrasi sangat terkait dengan inovasi layanan administrasi pasien mencakup inovasi peralatan administrasi, proses, teknologi informasi komunikasi, dan pengarsipan atau rekam jejak pasien.

\section{Kepuasan Konsumen (Pasien)}

Menurut Kotler (2005:36), kepuasan adalah perasaan senang atau kecewa seseorang yang berasal dari perbandingan antara kesan yang didapatkan terhadap kinerja atau hasil suatu produk dengan harapanharapannya. Menurut Engle et, al dalam Tjiptono (2004:24) mengatakan bahwa kepuasan konsumen merupakan evaluasi pembeli dimana alternatif yang dipilih sekurang-kurangnya sama atau melampaui harapan pelanggan, sedangkan ketidakpuasan timbul apabila hasil (outcome) tidak memenuhi harapan. Dari keseluruhan kegiatan yang dilakukan oleh sebuah lembaga kesehatan pada akhirnya akan bermuara pada nilai yang akan diberikan oleh pasien mengenai kepuasan yang dirasakan.

Banyak manfaat yang diterima oleh lembaga dengan tercapainya tingkat kepuasan pelanggan/pasien yang tinggi. Tingkat kepuasan pelanggan/pasien yang tinggi dapat meningkatkan loyalitas pelanggan, mengurangi sensitivitas pelanggan terhadap harga, mengurangi biaya promosi yang diakibatkan oleh meningkatnya jumlah pelanggan.

Pasien merupakan komponen penting dalam menilai tingkat profitabilitas secara lengkap yang dapat dicermati dari hasil analisis. Dengan pandangan ini, pasien dapat dinyatakan sebagai aset pemasaran di dalam bisnis terkait dengan kuantifikasi bagi perkiraannya. Oleh karena itu, retensi pasien merupakan suatu hal yang penting dan dibutuhkan. Hal mendasar untuk menjaga kemampuan mempertahankan profitabilitas adalah menjaga retensi pasien, di samping pengakuisisian pasien yang baru. Upaya untuk mendukung tingkat retensi yang tinggi adalah pelaksanaan aktivitas program pelayanan pasien yang dapat memberikan kepuasan. Tingkat kepuasan pasien diketahui dari total keseluruhan yang diperoleh. Semakin tinggi total yang diperoleh maka semakin tinggi pula tingkat kepuasan yang dirasakan oleh pasien. Begitu pula sebaliknya, semakin rendah total yang diperoleh maka semakin rendah pula tingkat kepuasan yang dirasakan oleh pasien.

Kepuasan pasien adalah nilai subjektif terhadap kualitas pelayanan yang diberikan. Penilaian subjektif tersebut didasarkan pada pengalaman masa lalu, pendidikan, situasi psikis, dan pengaruh lingkungan. Telah banyak dilakukan riset untuk menentukan kepuasan pasien, walaupun ini bukanlah suatu pekerjaan mudah, namun hal tersebut harus dilakukan agar pasien merasa puas atas pelayanan yang diberikan. Upaya untuk mengukur kepuasan pasien merupakan upaya yang sukar, karena bergantung pada tingkat aspirasi dan harapan yang ada, maka dapat ditarik kesimpulan bahwa pada dasarnya kepuasan pelanggan mencakup perbedaan antara harapan dan kinerja atau hasil yang dirasakan.

Hawkins dan Lonney dikutip dalam Tjiptono (2004:101) atribut (indicator) pembentuk kepuasan terdiri dari kesesuaian harapan, minat berkunjung kembali, dan kesediaan merekomendasikan. Kotler (2005:310) menjelaskan bahwa kepuasan konsumen berhubungan erat dengan kualitas produk dan jasa yang dihasilkan suatu perusahaan. Dengan tingkat kualitas yang tinggi akan menghasilkan kepuasan konsumen yang lebih tinggi juga. Menurut Tjiptono (2004:24) tujuan suatu perusahaan 
adalah menciptakan para konsumen atau pelanggan yang merasa puas atas produk yang dihasilkan oleh perusahaan.

Klinik Gracia selalu berupaya untuk menghasilkan kualitas pelayanan terhadap konsumen, salah satu strategi yang dilakukan klinik Gracia agar selalu medis dan berinovasi dalam layanan administrasi yang berlandaskan atas trend dan permintaan pasien sehingga akan memahami apa yang diinginkan oleh pasien yang pada akhirnya produk jasa yang ditawarkan dapat diterima dan memuaskan pasien.

\section{Kerangka Penelitian}

Kerangka pegaruh dari kualitas pelayanan medis dan inovasi layanan administrasi terhadap kepuasan pelanggan di klinik Gracia Bogor (secara teori, penelitian terdahulu, logika). Keterkaitan antar masing-masing variabel yang diteliti dapat diuraikan sebagai berikut:

Gambar 2

Kerangka/Konstelasi

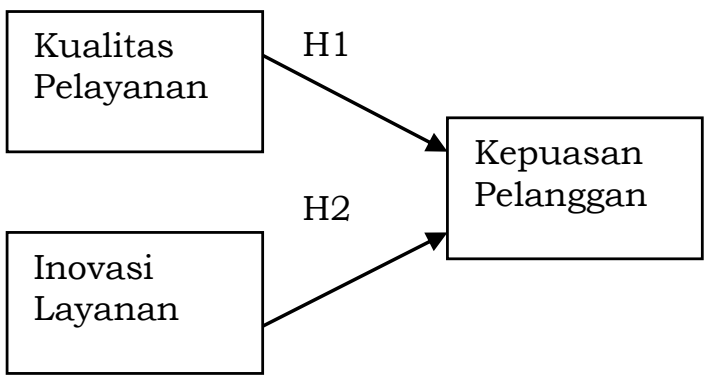

Pengaruh kualitas pelayanan medis sangat berpengaruh terhadap kepuasan pasien karena dengan kualitas pelayanan medis yang baik memberikan sebuah kontribusi positif terhadap perwujudan kepuasan pelanggan. Sebuah kualitas pelayanan medis yang baik akan memberikan nilai plus berupa motivasi khusus bagi pasien untuk terus melakukan pembelian ulang dan menjalin sebuah hubungan relasi.

Menurut Lewis dan Booms dalam Tjiptono (2007:121) mengemukakan bahwa kualitas pelayanan sebagai ukuran seberapa bagus tingkat layanan yang diberikan mampu sesuai dengan ekspektasi pelanggan. Sesuai dengan teori tersebut artinya adalah kualitas pelayanan medis merupakan salah satu yang menjadi faktor penentu kepuasan pasien sesuai dengan ekspektasi pasien tersebut. Selain itu, menurut Haynes dan Du Vall yang dikutip Ariani (2009:178) bahwa kualitas pelayanan merupakan proses yang secara konsisten meliputi pemasaran dan operasi yang memperhatikan keterlibatan orang, konsumen internal dan konsumen eksternal, dan memenuhi berbagai persyaratan dalam penyampaian jasa. Dari teori tersebut dapat disimpulkan bahwa kualitas pelayanan medis yang baik itu adalah prosesnya konsisten dan berkelanjutan dengan tujuan untuk memenuhi harapan pasien yang ada di klinik Gracia Bogor tersebut.

Dalam penelitian terdahulu Gunawan (2013) dan Muda (2014) membuat kesimpulan dari penelitian yang telah mereka lakukan bahwa kualitas pelayanan medis sangat berpengaruh positif signifikan terhadap kepuasan pelanggan dimana peneliti memberi gambaran bahwa dengan kualitas pelayanan medis yang baik dan terjamin serta memprioritaskan kepuasan pelanggan maka dengan cara tersebut dapat meningkatkan jumlah konsumen serta adanya loyalitas pada konsumen. Maka kualitas pelayanan medis terhadap kepuasan pelanggan ini sangat berpengaruh besar terhadap perusahaan.

H1: Ada pengaruh yang signifikan antara kualitas pelayanan medis terhadap kepuasan pasien pada Klinik Gracia Bogor.

Pengaruh inovasi layanan administrasi terhadap kepuasan pasien, inovasi layanan dapat diartikan kegiatan baru yang dilakukan perusahaan yang menghasilkan layanan baru, prosedur baru atau proses dari meningkatkan nilai tambah bagi jasa yang diberikan perusahaan. Inovasi yang dilakukan perusahaan akan membuat citra positif bagi perusahaan sehingga kepuasan pasien dapat terpenuhi. Inovasi layanan yang dilakukan perusahaan dapat diketahui melalui penggunaan teknologi bagi perusahaan, interaksi dengan konsumen dan pengembangan layanan baru (Delafrooz etal., 2013). 
Pada penelitian Hardianto (2017) dan Haqi (2017) mendapatkan kesimpulan bahwa dengan membuat inovasi layanan administrasi maka akan mampu meningkatkan pelayanan publik sekaligus meningkatkan efesiensi dan efektivitas dalam proses pelayanan administrasi. Dengan adanya inovasi pada layanan administrasi berbasis teknologi akan mampu mengurangi volume penumpukan antrian pendaftaran administrasi pada penyedia jasa kesehatan sehingga terwujud efesiensi, baik di pihak klinik maupun di pihak pasien.

H2: Ada pengaruh yang signifikan antara inovasi layanan adminstrasi terhadap kepuasan pasien pada Klinik Gracia Bogor.

\section{METODE PENELITIAN}

Penelitian ini melibatkan pasien Klinik Gracia yang beralamat di Pangkalan 9 Jalan Raya Narogong KM 23 No. 17 Limus Nunggal Cileungsi Bogor, Jawa Barat 16820. Penelitian dilaksanakan selama 6 (enam) bulan.

\section{Sampel Penelitian}

Populasi pada penelitian ini adalah pasien Klinik Gracia Bogor yang berjumlah 5000 orang. Sampel adalah bagian (subset) dari populasi yaitu sejumlah orang, peristiwa, benda, atau obyek tertentu yang dipilih dari populasi untuk mewakili populasi tersebut (Mulyanto dan Wulandari, 2010:100).

Sampel pada penelitian ini adalah sebagian dari 5000 pasien Klinik Gracia Bogor. Jumlah sampel ditentukan dengan rumus Slovin (Mulyanto dan Wulandari, 2010:103) dengan margin error $10 \%$ yaitu sebagai berikut:

$n=\frac{N}{1+N e^{2}}$

$n=\frac{5000}{1+\left(50000,1^{2}\right)}=98,039=100$

$\mathrm{n}=$ Jumlah Sampel Minimal

$\mathrm{N}=$ Jumlah Populasi

$\mathrm{e}=$ Margin Error 10\%

Agar memenuhi persyaratan minimal jumlah sampel dan memudahkan peneliti, maka jumlah sampel penelitian ditetapkan dibulatkan sebanyak 100 pasien. Insidental Sampling adalah teknik penentuan sampel berdasarkan kebetulan yaitu siapa saja pasien dari Klinik Gracia yang secara kebetulan atau incidental bertemu dengan peneliti dapat digunakan sebagai sampel, bila dipandang orang yang kebetulan ditemui itu cocok sebagai sumber data. Metode pengumpulan data dengan menggunakan observasi dan angket (kuesioner).

\section{Desain Penelitian}

Jenis penelitian yang digunakan dalam penelitian ini adalah explanatory research tipe kausal yang berupaya menguji pengaruh variabel independen terhadap variabel dependen. Lingkup penelitian ini adalah menguji pengaruh kualitas pelayanan medis dan inovasi layanan administrasi terhadap kepuasan pasien pada Klinik Gracia Bogor.

Terdapat 3 variabel pada penelitian ini yaitu 2 variabel independen dan satu variabel dependen. Variabel independen yang pertama yaitu kualitas pelayanan medis dengan simbol $\mathrm{X} 1$ dan variabel independen kedua yaitu inovasi layanan administrasi dengan simbol X2. Satu variabel dependen yaitu kepuasan pasien dengan simbol $\mathrm{Y}$.

\section{Operasionalisasi Variabel}

Operasionalisasi variabel penelitian dapat dikemukakan sebagai berikut:

Tabel 1

Operasionalisasi Variabel

\begin{tabular}{|c|c|c|c|}
\hline Variabel & $\begin{array}{c}\text { Definisi Operasional } \\
\text { Variabel }\end{array}$ & Indikator & Skala \\
\hline $\begin{array}{c}\text { Kualitas } \\
\text { Pelayanan } \\
\text { Medis (X1) }\end{array}$ & $\begin{array}{l}\text { Ukuran seberapa bagus } \\
\text { tingkat layanan yang } \\
\text { diberikan mampu sesuai } \\
\text { dengan ekspektasi } \\
\text { pelanggan. (Tjiptono, } \\
\text { 2007:121) }\end{array}$ & $\begin{array}{l}\text { 1. Tampilan Fisik } \\
\text { (tangibles) } \\
\text { 2. Keandalan } \\
\text { (reliability) } \\
\text { 3. Ketanggapan } \\
\text { (responsiveness) } \\
\text { 4. Jaminan } \\
\text { (assurance) } \\
\text { 5. Empati (empathv) }\end{array}$ & $\begin{array}{l}1-5 \\
1-5 \\
1-5 \\
1-5 \\
1-5\end{array}$ \\
\hline $\begin{array}{c}\text { Inovasi } \\
\text { Layanan } \\
\text { Administrasi } \\
\text { (X2) }\end{array}$ & $\begin{array}{l}\text { Suatu gagasan baru yang } \\
\text { diterapkan untuk } \\
\text { memprakarsai atau } \\
\text { memperbaiki suatu } \\
\text { produk atau proses dan } \\
\text { jasa. (Stephen Robbins, } \\
\text { 1994) } \\
\end{array}$ & $\begin{array}{l}\text { 1. Penggunaan } \\
\text { teknologi } \\
\text { 2. Interaksi dengan } \\
\text { konsumen } \\
\text { 3. Pengembangan } \\
\text { layanan baru }\end{array}$ & $\begin{array}{l}1-5 \\
1-5 \\
1-5\end{array}$ \\
\hline $\begin{array}{l}\text { Kepuasan } \\
\text { Pasien (Y) }\end{array}$ & $\begin{array}{l}\text { Perasaan senang atau } \\
\text { kecewa seseorang yang } \\
\text { berasal dari } \\
\text { perbandingan antara } \\
\text { kesan yang didapatkan } \\
\text { terhadap kinerja atau } \\
\text { hasil suatu produk } \\
\text { dengan harapan- } \\
\text { harapannya. (Kotler, } \\
\text { 2005) }\end{array}$ & $\begin{array}{l}\text { 1. Kesesuaian } \\
\text { Harapan } \\
\text { 2. Minat Penggunaan } \\
\text { Ulang } \\
\text { 3. Kesediaan untuk } \\
\text { Merekomendasika } \\
\mathrm{n}\end{array}$ & $\begin{array}{l}1-5 \\
1-5 \\
1-5\end{array}$ \\
\hline
\end{tabular}




\section{Metode Analisis}

Analisis yang digunakan dalam penelitian ini adalah deskriptif dan analisis verifikatif yaitu regresi linier ganda yang akan menghasilkan nilai koefisien determinasi (R Square). Analisis deskriptif dilakukan untuk menjelaskan responden dalam penelitian dan variable yang diteliti. Analisis regresi linier ganda digunakan untuk menguji pengaruh beberapa variable independen terhadap variable dependen. Analisis regresi linier berganda diawali dengan uji asumsi klasik. Uji asumsi klasik terdiri dari uji normalitas, multikolinieritas, autokorelasi, dan heteroskedastisitas.

Setelah uji asumsi klasik terpenuhi kemudian melakukan analisis regresi linier berganda yang menghasilkan nilai koefisien determinasi ( $\mathrm{R}$ Square), dan model persamaan regresi linier ganda $\mathrm{Y}=$ $\mathrm{a}+\mathrm{b} 1 \mathrm{X} 1+\mathrm{b} 2 \mathrm{X} 2$, kemudian dilakukan uji kelayakan model dengan Uji $\mathrm{F}$ untuk menentukan kelayakan model regresi linier ganda dalam menjelaskan pengaruh kualitas pelayanan medis dan inovasi layanan medis terhadap kepuasan pasien. Kemudian melakukan pengujian hipotesis penelitian dengan menggunakan uji t.

\section{HASIL DAN PEMBAHASAN Uji Asumsi Klasik Uji Normalitas}

Uji normalitas menunjukkan titiktitik menyebar di sekitar garis diagonal dan mengikuti arah garis diagonal atau grafik histogramnya menunjukan pola distribusi normal, maka model regresi memenuhi asumsi normalitas.

Gambar 3

Hasil Pengujian Normalitas

Normal Q-Q Plot of Residual

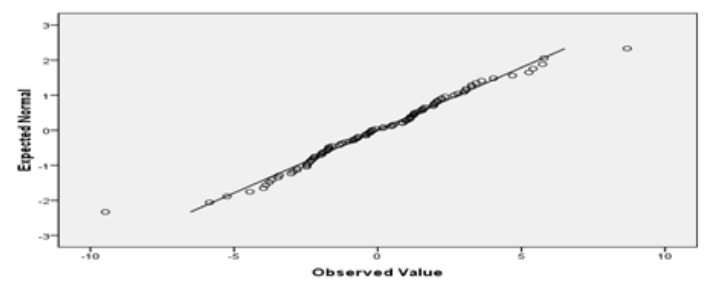

Sumber : Output angket SPSS 22.0 (2018)

\section{Uji Multikolinearitas}

Hasil uji multikolinearitas semua variable menunjukkan nilai tolerance >
0,1 dan VIF $<10$ maka dapat disimpulkan bahwa variabel bebas tersebut tidak terjadi masalah multikolinearitas.

Tabel 2

Hasil Pengujian Multikolinearitas

\begin{tabular}{|l|c|c|}
\hline \multirow{2}{*}{\multicolumn{1}{|c|}{ Model }} & \multicolumn{2}{|c|}{ Collinearity Statistics } \\
\cline { 2 - 3 } & Tolerance & VIF \\
\hline (Constant) & & \\
Kualitas Pelayanan Medis &, 658 & 1,520 \\
Inovasi Layanan Administrasi &, 658 & 1,520 \\
\hline
\end{tabular}

\section{Uji Autokorelasi}

Hasil uji autokorelasi nilai Durbin Watson (DW) nilai 1,94 artinya tidak terdapat autokorelasi pada penelitian ini (karena nilai DW 1,94 di antara 1.65 < DW $<2.35=$ tidak terjadi autokorelasi).

Tabel 3

Hasil Pengujian Autokorelasi

\begin{tabular}{|c|c|}
\hline Model & Durbin-Watson \\
\hline 1 & 1,944 \\
\hline
\end{tabular}

Sumber : Output angket SPSS 22.0 (2018)

\section{Uji Heteroskedastisitas}

Uji heteroskedasitas menunjukkan hasil titik-titik yang menyebar di atas dan di bawah angka 0 pada sumbu Y pada grafik Scatterplot, sehingga dapat dikatakan tidak terjadi heteroskedastisitas.

Gambar 4

Hasil Pengujian Heteroskedastisitas seatterplot

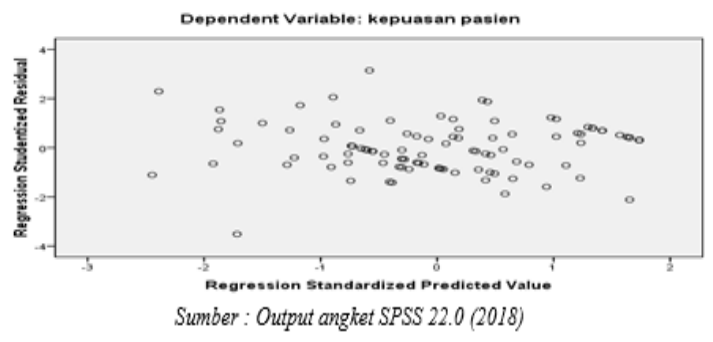

Analisis Regresi Linear Berganda

Tabel 4

Hasil Uji Regresi Linier Berganda

\begin{tabular}{|c|c|c|c|c|}
\hline \multirow{2}{*}{\multicolumn{2}{|c|}{ Model }} & $\begin{array}{c}\text { Unstandardized } \\
\text { Coefficients }\end{array}$ & $t$ & $\begin{array}{l}\text { Sig. } \\
, 000\end{array}$ \\
\hline & & B & & \multirow{4}{*}{$\begin{array}{l}, 000 \\
, 000\end{array}$} \\
\hline \multirow[t]{3}{*}{1} & (Constant) & 9,730 & 4,026 & \\
\hline & Kualitas Pelaranan Medis & 282 & 5715 & \\
\hline & Inovasi Lavanan Administrasi & 357 & 5,124 & \\
\hline
\end{tabular}

Sumber : Output angket SPSS 22.0 (2018)

Maka, dibuat persamaan regresi linear berganda sebagai berikut:

$$
\mathrm{Y}=9,730+0.282 \mathrm{X} 1+0,357 \mathrm{X} 2
$$


Tabel 5

Hasil Uji Koefisien Determinasi

\begin{tabular}{|c|c|c|c|}
\hline Model & $R$ & RSquare & Adjusted R Square \\
\hline 1 &, $770^{4}$ &, 593 &, 585 \\
\hline
\end{tabular}

Sumber : Output anghet SPSS 22.0 (2018)

$R$ square $\left(R^{2}\right)=0,593$ artinya bahwa model persamaan regresi linier ganda pada penelitian ini bahwa kepuasan pasien Klinik Gracia Bogor dapat dijelaskan/dipengaruhi oleh variabel kualitas pelayanan medis (X1) dan variabel inovasi layanan administrasi (X2) sebesar 59,3\% sedangkan sisanya $(100 \%-59,3 \%=40,7 \%)$ dijelaskan oleh variabel-variabel lain yang tidak termasuk dalam permodelan penelitian ini. Hal ini menunjukkan bahwa variabelvariabel bebas pada penelitian ini berkontribusi besar dalam memberikan informasi yang dibutuhkan untuk memprediksi variasi variabel terikat.

Tabel 6

Hasil Uji F

\begin{tabular}{|ll|c|c|}
\hline \multicolumn{1}{|c|}{ Model } & F & Sig. \\
\hline 1 & $\begin{array}{l}\text { Regression } \\
\text { Residual } \\
\text { Total }\end{array}$ & 70,786 &, $000^{\mathrm{b}}$ \\
\hline
\end{tabular}

Sumber : Output angket SPSS 22.0 (2018)

Berdasarkan tabel 6 di atas diketahui bahwa koefisien uji $\mathrm{F}$ diperoleh sebesar 70,786 dengan Sig F 0,000, sehingga perhitungan tersebut menunjukkan bahwa nilai signifikansi $\mathrm{F}$ lebih kecil daripada taraf signifikansi $(0,000<0,05)$, dengan demikian dapat disimpulkan bahwa Ho ditolak dan $\mathrm{Ha}$ diterima, artinya model hasil penelitian layak digunakan untuk menjelaskan pengaruh kualitas pelayanan medis dan inovasi layanan administrasi secara bersama-sama (simultan) terhadap kepuasan pasien pada Klinik Gracia.

\section{Uji Hipotesis (Parsial/Uji t)}

Tabel 7

Hasil Uji-t

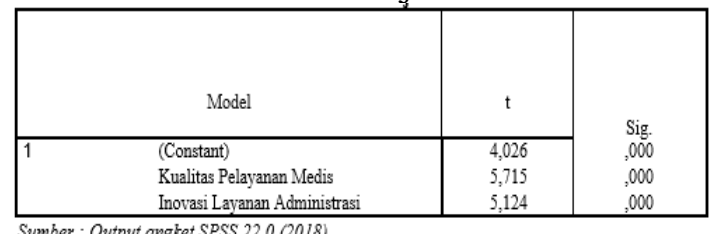

1. Hipotesis 1:

H1o ditolak dan H1a diterima, dimana nilai Sig. $\mathrm{t}<\mathrm{a} \quad(0.000<0.05)$ atau nilai $t$ hitung kualitas pelayanan medis 5,715 sementara untuk t tabel dengan Sig. $a=0,05$ dan $\mathrm{df}=\mathrm{n}-\mathrm{k}$ yaitu $100-3=97$, maka didapat $\mathrm{t}$ tabel (two tailed) sebesar 1,985. Nilai t hitung lebih besar dari nilai t tabel $(5,715>1,985)$ hal ini menunjukkan dan menyatakan bahwa terdapat pengaruh kualitas pelayanan medis terhadap kepuasan pasien dan signifikan.

2. Hipotesis 2:

H2o ditolak dan $\mathrm{H} 2 \mathrm{a}$ diterima, dimana nilai Sig. $\mathrm{t}<\mathrm{a}(0.000<0.05)$ atau nilai $t$ hitung inovasi layanan administrasi sebesar 5,124 sementara untuk t tabel dengan Sig. $\mathrm{a}=0,05$ dan $\mathrm{df}=\mathrm{n}-\mathrm{k}$ yaitu $100-3=$ 97, maka didapat t tabel (two tailed) sebesar 1,985. Nilai t hitung lebih besar dibandingkan nilai $\mathrm{t}$ table $(5,124>1,985)$ hal ini menunjukkan dan menyatakan bahwa terdapat pengaruh inovasi layanan adminitrasi terhadap kepuasan pasien dan signifikan.

\section{Pembahasan}

Kualitas merupakan bentuk aktivitas yang berlandaskan ilmu klinis yang dilakukan oleh Klinik Gracia guna memenuhi harapan pasiennya. Variabel inovasi layanan administrasi merupakan pengembangan dan implementasi gagasan-gagasan baru pada bagian administrasi Klinik Gracia yang dilakukan dengan berbagai aktivitas transaksi di dalam manajemen klinik dengan tujuan efesiensi dan efektifitas waktu, proses, tenaga dan biaya. Temuan ini sesuai dengan hasil penelitian Gunawan (2013) menunjukkan kualitas pelayanan medis berpengaruh dan signifikan terhadap tingkat kepuasan pasien. Hal ini menunjukkan semakin baik kualitas pelayanan medis maka semakin tinggi tingkat kepuasan pasien dalam menggunakan jasa pelayanan klinik Gracia Bogor dan sesuai juga dengan temuan penelitian yang dilakukan oleh Muslichati (2015) 
menunjukkan bahwa inovasi layanan berpengaruh secara parsial dan simultan terhadap kepuasan konsumen dan juga hasil temuan penelitian yang dilakukan oleh Hardianto (2017) menunjukkan bahwa inovasi layanan administrasi meningkatkan pelayanan sekaligus meningkatkan efisiensi dan efektivitas dalam penyelenggaraan sistem administrasi sehingga diharapkan dengan adanya inovasi pada layanan administrasi yang dilakukan oleh Klinik Gracia Bogor maka akan meningkatkan kepuasan pasien juga meningkatkan efisiensi dan efektifitas pada manajemen klinik baik itu dari segi proses, biaya, dan waktunya.

Temuan lain oleh peneliti sebelumnya Hardianto (2017) dengan indikator inovasi layanan administrasi melalui program sistem informasi desa (SIMAde) menyimpulkan bahwa inovasi layanan administrasi meningkatkan pelayanan publik sekaligus meningkatkan efesiensi dan efektivitas dalam penyelenggaraan sistem yang telah kuat dan mudah.

Mengingat hasil penelitian ini, maka untuk meningkatkan kepuasan pasien perlu meningkatkan kualitas pelayanan medis Klinik Gracia dengan cara melengkapi peralatan medisnya seperti alat USG pada poli kebidanan, ketanggapan dan keramahan tenagatenaga medis dan staff-staff perlu ditingkatkan. Ketepatan pembuatan jadwal bertemu dokter perlu ditingkatkan akurasi ketepatannya, sertifikat profesi tenaga medis, dan jaminan ijin praktek sebaiknya ditampilkan ruang tunggu untuk lebih meyakinkan pasien dan prinsip transparansi pelayanan. Juga pengambilan antrian pasien yang dapat dilakukan lewat telepon atau chat online dengan staff klinik perlu dipertahankan atau ditingkatkan. Selain itu, inovasi layanan administrasi tentang wacana yang dibangun oleh peneliti kepada responden (pasien Klinik Gracia) tentang pembuatan janji untuk bertemu dokter yang dapat dilakukan melalui website klinik secara online, inovasi tentang klinik melayani konsultasi pasien secara online (via telepon/video call/chating), inovasi tentang pasien klinik dapat menunggu antrian secara tidak langsung (berbasis online), inovasi tentang pembuatan resep dan penyampaian hasil diagnosis penyakit pasien yang dilakukan dengan sistem online (aplikasi khusus klinik), inovasi layanan tentang sistem jemput bola pada pasien yang membutuhkan (dokter mendatangi pasien).

\section{KESIMPULAN}

\section{Simpulan}

1. Kualitas pelayanan medis mempunyai pengaruh terhadap kepuasan pasien pada Klinik Gracia Bogor.

2. Inovasi layanan administrasi mempunyai pengaruh terhadap kepuasan pasien pada Klinik Gracia Bogor.

\section{Saran}

1. Klinik Gracia perlu untuk melengkapi peralatan medisnya seperti alat USG pada poli kebidanan, ketanggapan dan keramahan tenaga-tenaga medis, dan staff-staff perlu ditingkatkan. Ketepatan pembuatan jadwal bertemu dokter perlu ditingkatkan akurasi ketepatannya, sertifikat profesi tenaga medis dan jaminan ijin praktek sebaiknya ditampilkan ruang tunggu untuk lebih meyakinkan pasien dan prinsip transparansi pelayanan.

2. Pengambilan antrian pasien dilakukan lewat telepon atau chat online dengan staff klinik perlu dipertahankan atau ditingkatkan melalui inovasi layanan administrasi tentang pembuatan janji untuk bertemu dokter yang dapat dilakukan melalui website klinik secara online, inovasi konsultasi pasien secara online (via telepon/video call/chating), inovasi tentang pasien klinik dapat menunggu antrian secara tidak langsung (berbasis online), inovasi tentang pembuatan resep dan penyampaian hasil diagnosis penyakit pasien yang dilakukan dengan sistem online (aplikasi khusus klinik), inovasi layanan tentang sistem jemput bola 
pada pasien yang membutuhkan (dokter mendatangi pasien).

3. Manajemen Klinik Gracia disarankan untuk meneliti variabel-variabel yang tidak termasuk dalam permodelan penelitian ini, agar diketahui besaran nilai faktor-faktor lain yang mempengaruhi tingkat kepuasan pasien yang ada di Klinik Gracia Bogor.

\section{DAFTAR PUSTAKA}

Asmita, P. W. (2008). Analisis Pengaruh Pasien tentang Mutu Pelayanan Dokter terhadap Loyalitas Pasien di Poliklinik Umum Instalasi Rawat Jalan Rumah Sakit Panti Wilasa Citarum Semarang. Tesis. Semarang.

Changkaew, Laphasrada. (2012). Three Dimensions Model: Satge for Service Innovation in Hospital. Interdisciplinary Journal of Contemporary Research and Business, 4(2): 806.

Delafrooz, Narges et.al. (2013). The Impact of Service Innovation on Consumer Satisfaction. International Journal of Marketing and Technology 3 (2): p. 127.

Dhewanto, Wawan, dkk. (2014). Manajemen Inovasi Peluang Sukses Menghadapi Yogyakarta: Andi

Gunawan, Wely Hadi. (2013). Analisis Pengaruh Kualitas Pelayanan

Medis dan Pelayanan Administrasi terhadap Loyalitas. Skripsi Sarjana. Fakultas Diponegoro Semarang.

Haqi, Faisal. (2017). Inovasi Pelayanan Publik E-Health di Dinas Kesehatan Kota Surabaya. Skripsi Sarjana. Universitas Jember.
Hardianto, Fandam Nanang. (2017). Inovasi Layanan Administrasi Kependudukan Melalui Program Sistem Informasi Manajemen Desa (SIMAde) di Desa Ketapang Kecamatan Kalipuro Kabupaten Banyuwangi. Skripsi Sarjana. Universitas Jember.

Kotler dan Armstrong. (2009). PrinsipPrinsip Pemasaran (12 ed, Jilid 2). Jakarta: Erlangga.

Kotler, Philip dan Kevin Lane Keller. (2009). Manajemen Pemasaran. Jakarta: Erlangga.

Muda, Tryhaji Diwanshah. (2014). Analisis Pengaruh Kualitas Pelayanan dan Kualitas Tenaga Medis terhadap Kepuasan Pasien Rawat Inap di RSUD Kabupaten Batang, Skripsi Sarjana. Fakultas Diponegoro Semarang.

Mulyanto, H dan A. Wulandari. (2010). Penelitia: Metode dan Analisis, Semarang: CV. Agung.

Muslichati, Ela Zakiya. (2015). Pengaruh Kualitas Layanan dan Inovasi Layanan terhadap Kepuasan Konsumen pada Rumah Sakit Buah Hati di Kabupaten Kudus. Skripsi Sarjana. Universitas Negeri Semarang.

Parasuraman, A., Valerie A. Zeithmal and Leonard L. Berry. (1985). A Conceptual Model of Service Quality and Its Implication For Future Research. Journal of Marketing, 49(Fall).

Sulastiyono, Agus. (2006). Manajemen Penyelenggaraan Hotel. Bandung: Alfabeta.

Tjiptono, Fandy. (2000). Strategi Pemasaran. Yogyakarta: Andi. (2007). Pemasaran Jasa. Malang: Bayumedia. 